\title{
IMPLEMENTASI PROGRAM DANA ALOKASI KHUSUS (DAK) SUB BIDANG PRASARANA PEMERINTAHAN DAERAH TAHUN 2016
}

\author{
Mendra Wijaya \\ Dosen Program Studi Ilmu Pemerintahan, Fakultas IImu Sosial dan Ilmu \\ Politik, Universitas Islam Riau \\ mendra-wijaya@ymail.com \\ Handrisal \\ Dosen Program Studi IImu Pemerintahan, Fakultas Ilmu Sosial dan Politik, \\ Universitas Maritim Raja Ali Haji \\ handrisal.88@umrah.ac.id
}

\begin{abstract}
This study was chosen because of the government's policy to cut the budget for Specific Purpose Grant (DAK) in 2016. The DAK trimming of course had an impact on the implementation of regional development programs sourced from the DAK, especially for the Regional Government Infrastructure SubSector. Analysis of the data in this report is based on secondary data taken from DAK statistics and reporting in 19 provinces, activity reports, program documentation, and all materials available in the library and also in archive storage units or data. The study found that government policies by reducing $D A K$ budgets have had an influence in implementing DAK at the regional level, especially for the Regional Government Infrastructure Sub-Sector.
\end{abstract}

\section{Keywords: Implementation, Specific Purpose Grant, Regional Government Infrastructure Sub-Sector.}

\begin{abstract}
ABSTRAK
Kajian ini dipilih karena adanya kebijakan pemerintah untuk melakukan pemangkasan anggaran terhadap Dana Alokasi Khusus (DAK) pada tahun 2016. Pemangkasan DAK tersebut tentu saja berdampak pada implemntasi program pembangunan di daerah yang bersumber dari DAK terutama untuk Sub Bidang Prasarana Pemerintahan Daerah. Analisis data dalam laporan ini didasarkan pada data sekunder yang diambil dari statistik dan pelaporan DAK di 19 Provinsi, laporan kegiatan, dokumentasi program, dan semua bahan yang tersedia di perpustakaan dan juga di unit penyimpan arsip atau data. Hasil kajian menemukan bahwa kebijakan pemerintah dengan mamangkas anggaran DAK telah memberikan pengaruh dalam mengimplementasikan DAK di tingkat daerah terutama untuk Sub Bidang Prasarana Pemerintahan Daerah.
\end{abstract}

\section{Kata Kunci: Implementasi, Dana Alokasi Khusus, Sub-Bidang Prasarana Pemerintahan Daerah.}




\section{PENDAHULUAN}

Sejak bergulirnya penyelenggaraan desentralisasi yang dimulai pada tahun 2001, Pemerintah Pusat tetap memainkan peranan penting dalam mendukung pelaksanaan urusan pemerintah yang didesentralisasikan ke Pemerintah Daerah. Khususnya dalam hal keuangan. Untuk itu Pemerintah Pusat melakukan transfer dana ke daerah melalui beberapa mekanisme, seperti Dana Alokasi Umum (DAU), Dana Alokasi Khusus (DAK), Dana Bagi Hasil (DBH). Ketiga dana perimbangan tersebut mempunyai tujuan dan sifat dasar berlainan satu dengan yang lain. Semua dana perimbangan tersebut disalurkan kedalam Anggaran.

Pengertian DAK diatur dalam Pasal 1 angka 23 Undang-Undang Nomor 33 Tahun 2004 tentang Perimbangan Keuangan antara Keuangan Pusat dan Keuangan Daerah, yang menyebutkan bahwa : Dana Alokasi Khusus, selanjutnya disebut DAK adalah dana yang bersumber dari pendapatan APBN yang dialokasikan kepada daerah tertentu dengan tujuan untuk membantu mendanai kegiatan khusus yang merupakan urusan daerah dan sesuai dengan prioritas nasional.

Pelaksanaan DAK sendiri diarahkan pada kegiatan investasi pembangunan, pengadaan, peningkatan, dan/atau perbaikan sarana dan prasarana fisik pelayanan masyarakat dengan umur ekonomis yang panjang, termasuk pengadaan sarana fisik penunjang, dan tidak termasuk penyertaan modal.

DAK tidak dapat digunakan untuk mendanai administrasi kegiatan, penyiapan kegiatan fisik, penelitian, pelatihan, dan perjalanan dinas seperti pelaksanaan penyusunan rencana dan program, pelaksanaan tender pengadaan kegiatan fisik, kegiatan penelitian dalam rangka mendukung pelaksanaan kegiatan fisik, kegiatan perjalanan pegawai daerah dan kegiatan umum lainnya yang sejenis.

Pendapatan dan Belanja Daerah (APBD). Oleh karena itu dalam pengelolaannya Pemda harus mempertanggung-jawabkannya kepada Dewan Perwakilan Rakyat Daerah (DPRD). Disamping itu pemerintah pusat juga menyediakan pinjaman dan bantuan kepada Pemda. Tujuan transfer dana sebagaimana juga merupakan arah dari kebijakan fiskal pemerintah pusat 
dalam rangka penyelenggaraan otonomi daerah, antara lain untuk mengurangi kesenjangan fiskal antara pusat dan daerah, serta antar daerah dan mengurangi kesenjangan pelayanan publik antar daerah.

Menurut Halim (2002), DAK adalah dana yang berasal dari APBN yang dialokasikan kepada daerah untuk membantu membiayai kebutuhan tertentu. Berdasarkan Undang-Undang No. 104 Tahun 2000 Pasal 19 tentang Dana Perimbangan, disebutkan bahwa DAK dapat dialokasikan dari APBN kepada daerah tertentu untuk membantu membiayai kebutuhan khusus, dengan memperhatikan tersedianya dana dalam APBN.

Pengalokasian DAK memperhatikan ketersediaan dana dalam APBN, yang berarti bahwa besaran DAK tidak dapat dipastikan setiap tahunnya. DAK diberikan kepada daerah apabila daerah menghadapi masalah-masalah khusus. Pemerintah Pusat memberi pendelegasian wewenang kepada Pemerintah Daerah disertai dengan pengalihan dana, sarana dan prasarana serta Sumber Daya Manusia (SDM). Pengalihan dana diwujudkan dalam bentuk dana perimbangan yaitu Dana Alokasi Khusus (DAK). Berdasarkan Undang-undang No. 33 Tahun 2004, Dana Alokasi Khusus merupakan dana yang bersumber dari APBN yang dialokasokan kepada daerah tertentu dengan tujuan untuk membantu mendanai kegiatan khusus yang merupakan urusan daerah dan sesuai dengan prioritas nasional. Pemanfaatan DAK diarahkan pada kegiatan investasi pembangunan, pengadaan, peningkatan, dan perbaikan sarana dan prasarana fisik dengan umur ekonomis yang panjang, termasuk pengadaan sarana fisik penunjang, dan tidak termasuk penyertaan modal. Dengan adanya pengalokasian DAK diharapkan dapat mempengaruhi belanja modal, karena DAK cenderung akan menambah aset tetap yang dimiliki pemerintah guna meningkatkan pelayanan publik.

\section{TINJAUAN TEORITIS}

\section{A. Desentralisasi Fiskal}

Desentralisasi adalah asas penyelenggaraan pemerintahan yang dipertentangkan dengan sentralisasi. Desentralisasi menghasilkan pemerintahan lokal (local government), disana terjadi, "... a "superior" government - one encompassing a large jurisdiction assigns responsibility, 
authority, or function to 'lower' government unit - one encompassing a smaller jurisdiction - that is assumed to have some degree of authonomy. (Harry Friedman, dalam Cheema dan Dennis Rondinelli (Ed. 1985), Adanya pembagian kewenangan serta tersedianya ruang gerak yang memadai untuk memaknai kewenangan yang diberikan kepada unit pemerintahan yang lebih rendah (pemerintahan lokal), merupakan perbedaan terpenting antara konsep desentralisasi dan sentralisasi. Namun perbedaan konsep ini jelas menjadi remang-remang tatkala diterapkan dalam dinamika pemerintahan yang sebenarnya (Cheema dan Dennis Rondinelli, ibid).

Desentralisasi oleh Rondinelli dan Cheema didefinisikan cukup longgar, tetapi tergolong perspektif administrasi yaitu, "transfer or planning, decision making or administrative authority from central government to its field organizations, local administrative units, semi authonomous and parastatal organizations, local government, or non government organizations". (Peralihan kewenangan perencanaan, pengambilan keputusan, dan administrative dari pemerintah pusat ke organisasi lapangan, satuan administrative daerah, lembaga-lembaga semi otonom dan antar daerah (parastatal), pemerintah daerah, atau lembaga-lembaga swadaya masyarakat.

\section{B. Teori Pengeluaran Pemerintah}

Pemerintah tidak cukup hanya meraih tujuan akhir dari setiap kebijakan pengeluarannya, tetapi juga harus memperhitungkan sasaran antara yang akan menikmati atau terkena kebijakan tersebut. Memperbesar pengeluaran dengan tujuan semata-mata untuk meningkatkan pendapatan nasional atau memperluas kesempatan kerja adalah tidak memadai melainkan harus memperhitungkan siapa (masyarakat lapisan mana) yang bekerja atau meningkat pendapatannya. Pemerintah pun perlu menghindari agar peningkatan perannya dalam perekonomian justru melemahkan kegiatan pihak swasta.

Hubungan perkembangan pengeluaran pemerintah dengan tahaptahap pembangunan ekonomi yang dibedakan antara tahap awal, tahap menengah, dan tahap lanjut. Pada tahap awal perkembangan ekonomi, persentase investasi pemerintah terhadap total investasi besar sebab pada 
tahap ini pemerintah harus menyediakan prasarana seperti pendidikan, kesehatan, prasarana transportasi dan sebagainya (Mangkoesoebroto, 2002).

Pada tahap menengah pembangunan ekonomi, investasi pemerintah tetap diperlukan untuk meningkatkan pertumbuhan ekonomi agar dapat tinggal landas, namun pada tahap ini peran investasi swasta sudah semakin besar. Peran pemerintah tetap besar pada tahap menengah, oleh karena itu peran swasta yang semakin besar ini banyak menimbulkan kegagalan pasar (market failure), dan juga menyebabkan pemerintah harus menyediakan barang dan jasa publik dalam jumlah yang lebih banyak dan kualitas yang lebih baik. Selain itu, pada tahap ini perkembangan ekonomi menyebabkan terjadinya hubungan antar sektor yang sudah semakin rumit (complicated). Misalnya pertumbuhan ekonomi yang ditimbulkan oleh perkembangan sektor industri, makin tinggi tingkat pencemaran udara dan air, dan pemerintah harus turun tangan untuk mengatur dan mengurangi akibat negatif dari polusi itu terhadap masyarakat. Pemerintah juga harus melindungi buruh yang berada dalam posisi yang lemah agar dapat meningkatkan kesejahteraan mereka. Dalam suatu proses pembangunan menurut Musgrave, rasio investasi swasta dalam persentase terhadap GNP semakin besar dan persentase investasi pemerintah dalam persentase terhadap GNP akan semakin kecil.

Pada tingkat ekonomi yang lebih lanjut, Rostow berpendapat bahwa pembangunan ekonomi, aktivitas pemerintah beralih dari penyediaan prasarana pengeluaran-pengeluaran untuk aktivitas sosial seperti program kesejahteraan hari tua, program pelayanan kesehatan dan sebagainya (Mangkoesoebroto, 2002). Menurut Wagner ada lima hal yang menyebabkan pengeluaran pemerintah selalu meningkat. Kelima penyebab tersebut adalah tuntutan peningkatan perlindungan keamanan dan pertahanan, kenaikan tingkat pendapatan masyarakat, urbanisasi yang mengiringi pertumbuhan ekonomi, perkembangan demokrasi dan ketidakefisienan birokrasi yang mengiringi perkembangan pemerintah (Dumairy, 2006).

\section{Teori Resiko Fiskal}

Risiko fiskal adalah ketidak-pastian penerimaan dan/atau pengeluaran pemerintah. Risiko fiskal dapat membuat realisasi penerimaan dan/atau 
pengeluaran menjadi demikian berbeda dengan yang direncanakan dalam anggaran. Bila perbedaan realisasi dengan rencana menghasilkan situasi defisit atau meningkatkan defisit menjadi lebih tinggi dari yang diperkirakan pada saat perencanaan, maka pemerintah harus meningkatkan penerimaannya lewat penerbitan utang baru yang pada tahun berikutnya akan menjadi beban tambahan pada sisi pengeluaran.

Pengelolaan risiko fiskal yang lebih transparan memberikan berbagai manfaat.Manfaat tersebut adalah adanya pengawasan pelaksanaan fiskal beserta implikasinya.Memberikan informasi tentang kondisi fiskal yang lebih baik, sehingga mendorong kehati-hatian pengelolaan fiskal.Mempercepat respons mitigasi risiko fiskal yang lebih baik pada saat terjadi goncangan dan kebijakan fiskal yang lebih baik untuk menghadapi adanya guncangan tersebut (Everaert et al, 2009). Dengan demikian, upaya pemerintah Indonesia untuk secara transparan menjalankan pengelolaan fiskal akan membantu mengantisipasi dampak guncangan faktor eksternal dan internal terhadap ketahanan fiskal dan dapat segera menentukan kebijakan untuk meredakan dampak negatif guncangan tersebut.

Ada banyak hal yang dapat memunculkan risiko fiskal, demikian juga akibat yang dapat dimunculkan dari terjadinya peristiwa yang menjadi risiko. Kerangka analisis risiko fiskal pada dasarnya menyajikan berbagai jenis risiko fiskal berdasarkan penyebab dan atau akibat yang dimunculkannya. Dalam studi ini, dibahas dimensi risiko fiskal sebagaimana dikembangkan oleh Brixi (2001) dan Cottarelli (2014).

Brixi (2001) dan kemudian dilanjutkan oleh Brixi \& Mody (2002) memilah risiko fiskal berdasarkan dua dimensi, yaitu dimensi ada tidaknya ketentuan perundangan-undangan untuk pelaksanaan kewajiban (liabilities) tertentu, dan dimensi kepastian pelaksanaan kewajiban (liabilities) tersebut. Dimensi ada tidaknya ketentuan hukum yang menjadi dasar kewajiban pemerintah memisahkan kewajiban keuangan pemerintah menjadi kewajiban eksplisit (explicit liabilities) dan kewajiban implisit (implicit liabilities), sedangkan dimensi kepastian dilakukannya kewajiban memisahkan kewajiban keuangan pemerintah menjadi kewajiban langsung (directliabilities) dan kewajiban yang kontinjen (contingent liabilities). Kombinasi dari dua dimensi tersebut menghasilkan 4 kategori risiko fiskal, yaitu: direct explicit liabilities, 
contingent explicit liabilities, direct implicit liabilities, dan contingent implicit liabilities.

\section{Dana Perimbangan}

Dalam penyelenggaraan Otonomi Daerah yang dilaksanakan dengan prinsip-prinsip Demokrasi, serta memperhatikan potensi dan keanekaragaman Daerah. Untuk itu dituntut kesiapan Daerah untuk meningkatkan sumber daya manusia dan sumber-sumber pendukung, dan penentu untuk bergerak majunya masyarakat Daerah ke arah yang lebih sejahtera, dalam prinsipprinsip pembangunan yang berkelanjutan. Pemerintah Pusat tidak lebih dari sekedar fasilitator dalam proses-proses itu. Keputusan dan kebijakan yang di ambil tidak lagi tergantung pada Pemerintah Pusat melainkan sudah merupakan kewenangan Pemerintah Daerah yang menentukannya, bukan berdasarkan kehendak atau kepentingan Aparat Pemerintah Pusat semata.

Berdasarkan kewenangan yang dimiliki oleh Daerah, maka pelaksanaan penyelenggaraan Otonomi Daerah memerlukan pembiayaan yang di tanggung oleh Daerah melalui Anggaran Pendapatan dan Belanja Daerah (APBD), sehingga perlu diatur Perimbangan Keuangan Antara Pemerintah Pusat Dan Daerah sebagaimana tertuang dalam Undang-Undang Nomor 33 Tahun 2004, dan setiap daerah harus mampu menggali sumbersumber keuangan yang ada di daerahnya masing-masing, yang dimaksud dengan dana perimbangan adalah dana yang bersumber dari pendapatan, Anggaran Pendapatan dan Belanja Negara (APBN) yang dialokasikan pada daerah untuk mendanai kebutuhan daerah dalam rangka pelaksanaan desentralisasi. Dana perimbangan bertujuan mengurangi kesenjangan fisikal antara Pemerintah, Pemerintahan Pusat dan antar Pemerintah Daerah Sejalan dengan hal itu Pemerintah Daerah harus lebih menekankan peranan dan fungsinya masing-masing terutama fungsi legislatif, fungsi pengawasan, maupun fungsi anggaran dalam penyelenggaraan pemerintah daerah. Dana Perimbangan terdiri:

a. Dana Bagi Hasil

Dana Bagi Hasil adalah dana yang bersumber dari Anggaran Pendapatan dan Belanja Negara (APBN) yang dialokasikan kepada daerah berdasarkan angka persentase untuk mendanai kebutuhan daerah dalam 
rangka pelaksanaan desentralisasi. Dana Bagi Hasil ini bersumber dari pajak dan kekayaan daerah dimana menurut pasal 11 ayat 1 UU No. 33 Tahun 2004, dana bagi hasil yang berasal dari pajak terdiri dari Pajak Bumi dan Bangunan (PBB), Bea Perolehan Hak atas Tanah dan Bangunan (BPHTB), Pajak Penghasilan (PPh).

b. Dana Alokasi Umum

Dana Alokasi Umum adalah dana yang bersumber dari Anggaran Pendapatan dan Belanja Negara (APBN) yang dialokasikan dengan tujuan pemerataan kemampuan keuangan antar daerah untuk mendanai kebutuhan daerah dalam dalam rangka pelaksanaan desentralisasi.

c. Dana Alokasi Khusus

Dana Alokasi Khusus adalah dana yang bersumber dari pendapatan Anggaran Pendapatan dan Belanja Negara (APBN) yang dialokasikan kepada daerah tertentu dengan tujuan membantu mendanai kegiatan khusus yang merupakan urusan daerah dan sesuai dengan perioritas nasional. Sesuai dengan Undang-Undang No. 33 Tahun 2004 tentang perimbangan keuangan antara Pemerintah Pusat dan Pemerintah Daerah.

Pengertian dana alokasi khusus menurut UU No. 33 Tahun 2004 adalah dana yang berasal dari APBN yang dialokasikan kepada daerah untuk membantu membiayai kebutuhan khusus, termasuklah yang berasal dari dana reboisasi. Kebutuhan khusus yang dimaksud yaitu :

1. Kebutuhan yang tidak dapat diperkirakan dengan menggunakan rumus alokasi umum, dan/atau

2. Kebutuhan yang merupakan komitmen atau prioritas nasional.

Dana alokasi khusus (DAK) merupakan salah satu mekanisme transfer keuangan Pemerintah Pusat ke daerah yang bertujuan antara lain untuk meningkatkan penyediaan sarana dan prasarana fisik daerah sesuai prioritas nasional serta mengurangi kesenjangan laju pertumbuhan antar daerah dan pelayanan antar bidang. DAK memainkan peran penting dalam dinamika pembangunan sarana dan prasarana pelayanan dasar di daerah karena sesuai dengan prinsip desentralisasi tanggung jawab dan akuntabilitas bagi penyediaan pelayanan dasar masyarakat telah dialihkan kepada pemerintah daerah. 
Dana alokasi khusus merupakan dana yang dialokasikan dari APBN ke Daerah tertentu untuk mendanai kebutuhan khusus yang merupakan urusan daerah dan juga prioritas nasional antara lain: kebutuhan kawasan transmigrasi, kebutuhan beberapa jenis investasi atau prasarana, pembangunan jalan di kawasan terpencil, saluran irigasi primer, termasuk didalamnya prasarana pemerintahan daerah.

\section{METODE PENELITIAN}

\section{A. Analisis Data}

Analisis data dalam laporan ini didasarkan pada data sekunder. Data sekunder diambil dari statistik dan pelaporan DAK di 19 Provinsi, laporan kegiatan, dokumentasi program, dan semua bahan yang tersedia di perpustakaan dan juga di unit penyimpan arsip atau data.

\section{B. Pengolahan Data}

Analisis data disesuaikan dengan keluaran yang akan diperoleh dari data sekunder. Dari analisis ini diharapkan mampu memunculkan alternatif kebijakan, arahan strategi, dan program-program dan skenario kinerja serta sistem koordinasi dalam rangka mendukung optimalisasi pengembangan Dana Alokasi Khusus (DAK) Sub Bidang Prasarana Pemerintahan kedepan.

Data lapangan yang diperoleh dari laporan daerah yang disajikan dalam bentuk tabulasi dan grafik. Grafik merupakan hasil pengolahan data yang dapat memudahkan dalam memahami data. Tabulasi data adalah penyajian data ke dalam bentuk tabel atau diagram untuk memudahkan pengamatan atau evaluasi.

\section{Daerah Sampel}

Untuk pencapaian sasaran dilakukan evaluasi dokumen daerah penerima Dana Alokasi Khusus (DAK) Praspem dengan penetapan lokasi pada 19 provinsi (yaitu ; Aceh, Sumatera Utara, Sumatera Barat, Sumatera Selatan, Lampung, Banten, Jawa Barat, Jawa Tengah, Jawa Timur, Kalimantan Barat, Kalimantan Tengah, Sulawesi Barat, Sulawesi Utara, Bali, Nusa Tenggara Barat, Nusa Tenggara Timur, Maluku, Maluku Utara, dan 
Papua). Penetapan daerah sampel tersebut dilakukan dengan menggunakan teknik purposive sampling.

\section{Analisis dan Pembahasan Implementasi Dana Alokasi Khusus Sub Bidang Prasarana Pemerintahan}

\section{A. Arah dan Kebijakan Dana Alokasi Khusus Sub Bidang Prasarana Pemerintahan}

Secara khusus maksud dari dana perimbangan, utamanya Dana Alokasi Umum (DAU) dan Dana Alokasi Khsusus (DAK). Dana perimbangan merupakan pendanaan daerah yang bersumber dari APBN yang terdiri atas Dana Bagi Hasil (DBH), Dana Alokasi Umum (DAU), dan Dana Alokasi Khusus (DAK). Menurut sejumlah literatur, dana perimbangan memiliki makna yang sama dengan pendapatan transfer. Salah satu bentuk pendapatan transfer adalah bantuan (grants). Bantuan (grants) menjadi sumber pendapatan yang utama bagi pemerintah daerah di banyak negara. Istilah lain dari grants yang juga seringkali dipergunakan adalah subsidies atau subventions. Terdapat tiga alasan utama dari penggunaan jenis bantuan ini yakni: untuk menambah sumber pendapatan daerah, lalu untuk memenuhi kebutuhan yang berlebihan pendapatan yang terbatas dari area tertentu, dan untuk meningkatkan program tertentu serta menyelipkan kontrol terhadapnya.

Dalam pasal 285 Undang-Undang Nomor 23 Tahun 2014 tentang Pemerintahan Daerah berbunyi;

(1) Sumber pendapatan Daerah terdiri atas:

a. pendapatan asli Daerah meliputi:

1. pajak daerah;

2. retribusi daerah;

3. hasil pengelolaan kekayaan Daerah yang dipisahkan; dan

4. lain-lain pendapatan asli Daerah yang sah;

b. pendapatan transfer; dan

c. Iain-lain pendapatan Daerah yang sah. 
352 | Mendra Wijaya, Handrisal.Implementasi Program...|

(2) Pendapatan transfer sebagaimana dimaksud pada ayat (1) huruf b meliputi:

a. transfer Pemerintah Pusat terdiri atas:

1. dana perimbangan;

2. dana otonomi khusus;

3. dana keistimewaan; dan

4. dana Desa.

b. transfer antar-Daerah terdiri atas:

1. pendapatan bagi hasil; dan

2. bantuan keuangan.

Pasal 288 berbunyi, Dana perimbangan terdiri atas Dana Bagi Hasil (DBH), Dana Alokasi Umum (DAU) dan Dana ALokasi Khusus (DAK). Kemudian Pasal 292 berbunyi :

(1) DAK sebagaimana dimaksud dalam Pasal 288 huruf c bersumber dari APBN dialokasikan pada Daerah untuk mendanai kegiatan khusus yang merupakan Urusan Pemerintahan yang menjadi kewenangan Daerah.

(2) Kebijakan DAK dibahas dalam forum dewan pertimbangan otonomi daerah sebelum penetapan rencana kerja Pemerintah Pusat.

(3) Menteri teknis/kepala lembaga pemerintah nonkementerian mengusulkan kegiatan khusus kepada kementerian yang menyelenggarakan perencanaan pembangunan nasional dan kementerian yang menyelenggarakan urusan pemerintahan bidang keuangan.

(4) Menteri yang menyelenggarakan urusan pemerintahan bidang perencanaan pembangunan nasional mengoordinasikan usulan kegiatan khusus sebagaimana dimaksud pada ayat (3) dengan Menteri, kementerian yang menyelenggarakan urusan pemerintahan bidang keuangan, dan gubernur sebagai wakil Pemerintah Pusat untuk ditetapkan dalam rencana kerja Pemerintah Pusat sebagai kegiatan khusus yang akan didanai DAK. 
(5) Kegiatan khusus yang telah ditetapkan dalam rencana kerja Pemerintah Pusat sebagaimana dimaksud pada ayat (4) menjadi dasar pengalokasian DAK.

(6) Alokasi DAK sebagaimana dimaksud pada ayat (5) per Daerah ditetapkan oleh kementerian yang menyelenggarakan urusan pemerintahan bidang keuangan.

Lebih lanjut Dana Alokasi Khusus (DAK) diatur dalam Petunjuk Teknis melalui Peraturan Menteri Dalam Negeri Republik Indonesia Nomor 85 Tahun 2015 Tentang Petunjuk Teknis Penggunaan Dana Alokasi Khusus Sub-Bidang Prasarana Pemerintahan Daerah, Sub-Bidang Sarana dan Prasarana Satuan Polisi Pamong Praja, Sub-Bidang Sarana dan Prasarana Pemadam Kebakaran, dan Sub-Bidang Transportasi Perdesaan.

Di dalam konsideran Permendagri No. 85 Tahun 2015 menegaskan bahwa dalam rangka mendorong pembangunan daerah dan sasaran prioritas nasional, diperlukan dukungan penyediaan prasarana pemerintahan di daerah dan transportasi perdesaan, yang dilaksanakan melalui Dana Alokasi Khusus Sub-Bidang Prasarana Pemerintahan Daerah, Sub-Bidang Sarana Dan Prasarana Satuan Polisi Pamong Praja, Sub-Bidang Sarana Dan Prasarana Pemadam Kebakaran, dan Sub-Bidang Transportasi Perdesaan; kemudian berdasarkan Pasal 59 ayat (1) Peraturan Pemerintah Nomor 55 tahun 2005 tentang Dana Perimbangan, perlu disusun petunjuk teknis penggunaan Dana Alokasi Khusus Sub-Bidang Prasarana Pemerintahan Daerah, Sub-Bidang Sarana Dan Prasarana Satuan Polisi Pamong Praja, Sub-Bidang Sarana Dan Prasarana Pemadam Kebakaran, dan Sub-Bidang Transportasi Perdesaan yang ditetapkan dengan Peraturan Menteri. Pada Pasal 2 Permendagri 85 Tahun 2015 menyatakan bahwa:

(1) DAK yang dikoordinasikan Kementerian Dalam Negeri, meliputi:

a. DAK Bidang Prasarana Pemda; dan

b. DAK Bidang Transportasi.

(2) DAK Bidang Prasarana Pemda sebagaimana dimaksud pada ayat (1) huruf a, terdiri dari:

a. DAK Sub-Bidang Prasarana Pemda; 
354 | Mendra Wijaya, Handrisal.Implementasi Program...|

b. DAK Sub-Bidang Sarpras Satpol PP; dan

c. DAK Sub-Bidang Sarpras Damkar.

Berikut Dana Alokasi Khusus Sub-Bidang Prasarana Pemerintahan Daerah berdasarkan Peraturan Presiden No. 137 Tahun 2015 Tentang Rincian Anggaran Pendapatan Dan Belanja Negara Tahun Anggaran 2016 Rincian Dana Alokasi Khusus Fisik Menurut Provinsi/Kabupaten/Kota :

TABEL 4.1

DAK Sub-Bidang Prasarana Pemerintahan Daerah

\begin{tabular}{|c|c|c|}
\hline \multirow[b]{2}{*}{ No } & \multirow[b]{2}{*}{ Nama Daerah } & Bidang Prasarana Pemda \\
\hline & & $\begin{array}{c}\text { Sub Bidang Prasarana } \\
\text { Pemda }\end{array}$ \\
\hline 1. & $\begin{array}{l}\text { Provinsi Aceh } \\
\text { Kabupaten Aceh Selatan } \\
\text { Kabupaten Aceh Tengah } \\
\text { Kabupaten Gayo Luwes } \\
\text { Kabupaten Pidie Jaya } \\
\text { Kota Subulussalam }\end{array}$ & $\begin{array}{l}3.544,22 \\
2.085,79 \\
4.245,71 \\
4.245,71 \\
5.087,29\end{array}$ \\
\hline 2. & $\begin{array}{l}\text { Provinsi Sumatera Utara } \\
\text { Kabupaten Nias } \\
\text { Kabupaten Tapanuli Tengah } \\
\text { Kabupaten Tapanuli Utara } \\
\text { Kabupaten Pakpak Bharat } \\
\text { Kabupaten Padang Lawas }\end{array}$ & $\begin{array}{l}5.087,29 \\
4.771,97 \\
3.096,24 \\
2.568,48 \\
1.316,99\end{array}$ \\
\hline 3. & $\begin{array}{l}\text { Provinsi Sumatera Barat } \\
\text { Kabupaten Pesisir Selatan }\end{array}$ & $1.826,79$ \\
\hline 4. & $\begin{array}{l}\text { Provinsi Riau } \\
\text { Kabupaten Kepulauan Meranti }\end{array}$ & 521,85 \\
\hline 5. & Provinsi Jambi & \\
\hline
\end{tabular}




\begin{tabular}{|c|c|c|}
\hline No & Nama Daerah & $\begin{array}{c}\text { Bidang Prasarana Pemda } \\
\text { Sub Bidang Prasarana } \\
\text { Pemda }\end{array}$ \\
\hline 6. & $\begin{array}{l}\text { Provinsi Sumatera Selatan } \\
\text { Kota Prabumulih } \\
\text { Kota Pagar Alam } \\
\text { Kabupaten Banyuasin } \\
\text { Kabupaten Penukal Abab Lematang } \\
\text { Ilir } \\
\text { Kabupaten Musi Rawas Utara }\end{array}$ & $\begin{array}{r}501,72 \\
289,93 \\
3.175,37 \\
3.485,41 \\
635,99\end{array}$ \\
\hline 7. & Provinsi Bengkulu & - \\
\hline 8. & $\begin{array}{l}\text { Provinsi Lampung } \\
\text { Kabupaten Lampung Selatan } \\
\text { Kabupaten Pringsewu } \\
\text { Kabupaten Pesisir Barat }\end{array}$ & $\begin{array}{r}445,81 \\
1.408,54 \\
518,41\end{array}$ \\
\hline 9. & $\begin{array}{l}\text { Provinsi DKI Jakarta } \\
\text { - }\end{array}$ & - \\
\hline 10. & $\begin{array}{l}\text { Provinsi Jawa Barat } \\
\text { Kabupaten Kuningan } \\
\text { Kabupaten Pangandaran }\end{array}$ & $\begin{array}{l}7.657,70 \\
2.261,40\end{array}$ \\
\hline 11. & $\begin{array}{l}\text { Provinsi Jawa Tengah } \\
\text { Kabupaten Karanganyar } \\
\text { Kabupaten Sragen }\end{array}$ & $\begin{array}{r}351,13 \\
7.576,56\end{array}$ \\
\hline 12. & $\begin{array}{l}\text { Provinsi DI Yogyakarta } \\
-\end{array}$ & - \\
\hline 13. & $\begin{array}{l}\text { Provinsi Jawa Timur } \\
\text { Kabupaten Probolinggo } \\
\text { Kabupaten Situbondo }\end{array}$ & $\begin{array}{l}6.295,74 \\
1.968,05\end{array}$ \\
\hline
\end{tabular}


356 | Mendra Wijaya, Handrisal.Implementasi Program...|

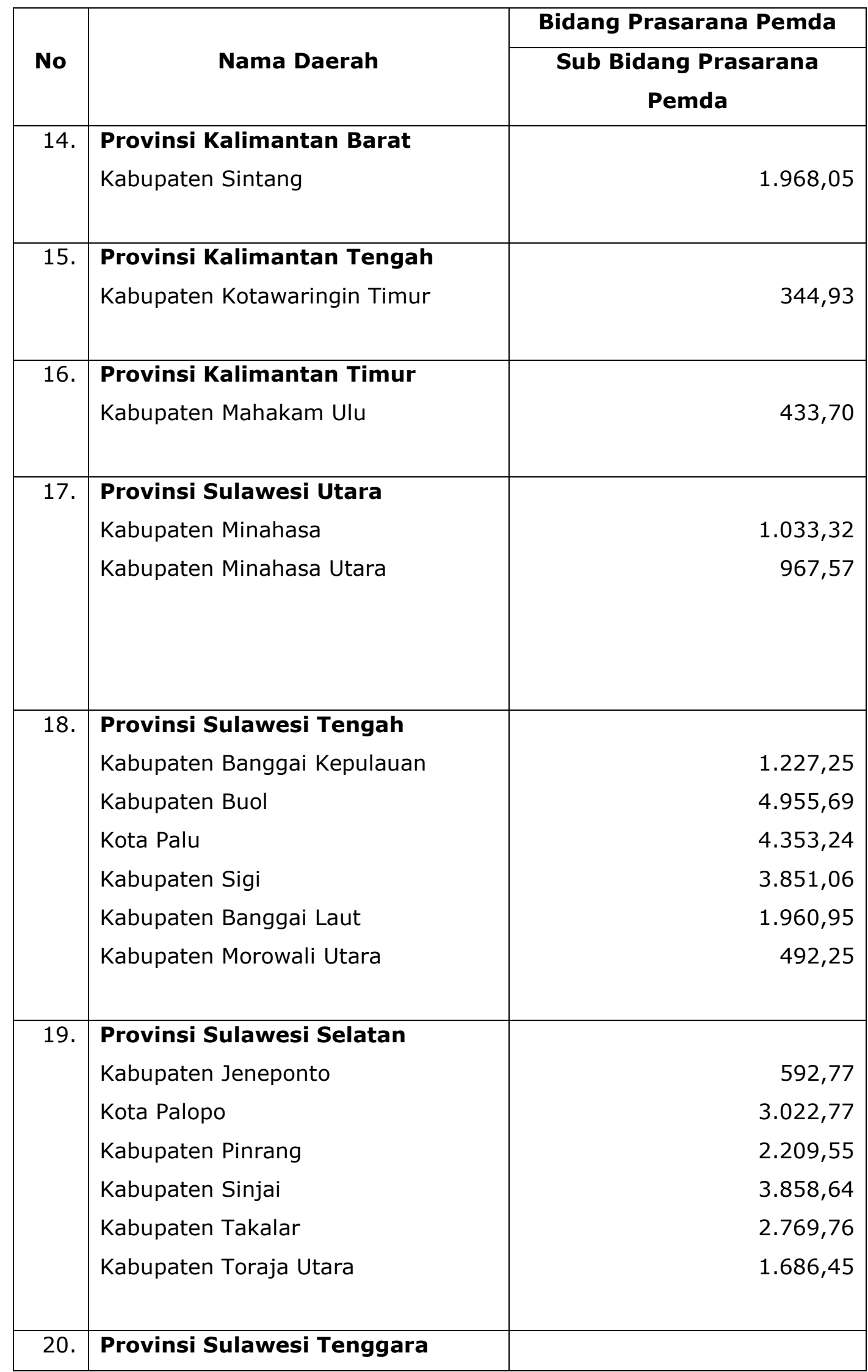




\begin{tabular}{|c|c|c|}
\hline No & Nama Daerah & $\begin{array}{c}\text { Bidang Prasarana Pemda } \\
\text { Sub Bidang Prasarana } \\
\text { Pemda }\end{array}$ \\
\hline & $\begin{array}{l}\text { Kabupaten Kolaka Utara } \\
\text { Kabupaten Konawe Kepulauan } \\
\text { Kabupaten Kolaka Timur } \\
\text { Kabupaten Muna Barat } \\
\text { Kabupaten Buton Tengah } \\
\text { Kabupaten Buton Selatan }\end{array}$ & $\begin{array}{r}297,20 \\
2.553,17 \\
2.439,75 \\
721,94 \\
2.594,93 \\
397,51\end{array}$ \\
\hline 21. & $\begin{array}{l}\text { Provinsi Bali } \\
\text { Kabupaten Bangli }\end{array}$ & $1.484,20$ \\
\hline 22. & $\begin{array}{l}\text { Provinsi Nusa Tenggara Barat } \\
\text { Kabupaten Dompu } \\
\text { Kabupaten Lombok Tengah }\end{array}$ & $\begin{array}{l}1.896,79 \\
2.571,33\end{array}$ \\
\hline 23. & $\begin{array}{l}\text { Provinsi Nusa Tenggara Timur } \\
\text { Kabupaten Alor } \\
\text { Kabupaten Belu } \\
\text { Kabupaten Ende }\end{array}$ & $\begin{array}{r}786,19 \\
1.365,41 \\
398,08\end{array}$ \\
\hline 24. & $\begin{array}{l}\text { Provinsi Maluku } \\
\text { Kabupaten Maluku Tenggara } \\
\text { Kabupaten Maluku Barat Daya }\end{array}$ & $\begin{array}{l}536,78 \\
530,50\end{array}$ \\
\hline 25. & $\begin{array}{l}\text { Provinsi Papua } \\
\text { Kabupaten Kepulauan Yapen } \\
\text { Kabupaten Tolikara } \\
\text { Kabupaten Lanny Jaya } \\
\text { Kabupaten Dogiyai }\end{array}$ & $\begin{array}{r}2.224,10 \\
6.704,31 \\
5.994,26 \\
733,48\end{array}$ \\
\hline 26. & $\begin{array}{l}\text { Provinsi Maluku Utara } \\
\text { Kabupaten Halmahera Barat }\end{array}$ & $2.767,18$ \\
\hline
\end{tabular}


358 | Mendra Wijaya, Handrisal.Implementasi Program...|

\begin{tabular}{|c|c|c|}
\hline No & Nama Daerah & $\begin{array}{c}\text { Bidang Prasarana Pemda } \\
\text { Sub Bidang Prasarana } \\
\text { Pemda }\end{array}$ \\
\hline & Kabupaten Pulau Taliabu & $7.233,29$ \\
\hline 27. & $\begin{array}{l}\text { Provinsi Banten } \\
\text { Kabupaten Pandeglang } \\
\text { Kabupaten Serang }\end{array}$ & $\begin{array}{l}2.444,12 \\
4.495,14\end{array}$ \\
\hline 28. & Provinsi Bangka Belitung & \\
\hline 29. & $\begin{array}{l}\text { Provinsi Gorontalo } \\
\text { Kabupaten Pohuwato }\end{array}$ & $2.097,35$ \\
\hline 30. & $\begin{array}{l}\text { Provinsi Kepulauan Riau } \\
\text { Kabupaten Kepulauan Anambas }\end{array}$ & $1.423,96$ \\
\hline 31. & $\begin{array}{l}\text { Provinsi Papua Barat } \\
\text { Kabupaten Maybrat } \\
\text { Kabupaten Manokwari Selatan } \\
\text { Kabupaten Pegunungan Arfak }\end{array}$ & $\begin{array}{r}323,02 \\
566,50 \\
2.580,02\end{array}$ \\
\hline 32. & $\begin{array}{l}\text { Provinsi Sulawesi Barat } \\
\text { Kabupaten Mamuju Tengah }\end{array}$ & $2.520,68$ \\
\hline 33. & $\begin{array}{l}\text { Provinsi Kalimantan Utara } \\
\text { Kabupaten Nunukan }\end{array}$ & $\begin{array}{r}5.709,94 \\
446,35\end{array}$ \\
\hline 34. & Kalimantan Selatan & \\
\hline
\end{tabular}


Undang-Undang No. 33 Tahun 2004 mengatur bahwa pengalokasian DAK ditetapkan berdasarkan tiga kriteria yang meliputi kriteria umum, kriteria khusus, dan kriteria teknis.

(i) Kriteria umum didasarkan pada pertimbangan kemampuan keuangan pemda dengan prioritas pada daerah yang selisih penerimaan umumnya dengan belanja pegawai nol atau negatif atau berada di bawah rata-rata nasional berdasarkan indeks fiskal neto.

(ii) Kriteria khusus disusun dengan memperhatikan peraturan perundangan, seperti daerah otonomi khusus, dan karakteristik daerah, misalnya daerah pantai, kepulauan, perbatasan, dll.

(iii) Kriteria teknis didasarkan pada pertimbangan yang ditentukan oleh departemen teknis/kementerian negara dengan menggunakan indikator yang dapat menggambarkan kondisi sarana dan prasarana pada setiap bidang.

Dana Alokasi Khusus (DAK) atau specific purpose grant adalah dana yang bersumber dari pendapatan APBN yang dialokasikan kepada daerah tertentu dengan tujuan untuk membantu mendanai kegiatan khusus yang merupakan urusan daerah dan sesuai dengan prioritas nasional. Dana Alokasi Khusus (DAK) dimaksudkan untuk mendanai kegiatan khusus yang menjadi urusan daerah dan merupakan prioritas nasional, sesuai dengan fungsi yang merupakan perwujudan tugas kepemerintahan di bidang tertentu, khususnya dalam upaya pemenuhan kebutuhan sarana dan prasarana pelayanan dasar masyarakat. Kegiatan khusus tersebut sesuai dengan fungsi yang telah ditetapkan dalam APBN. Kegiatan khusus yang ditetapkan oleh pemerintah mengutamakan kegiatan pembangunan dan/atau pengadaan dan/atau peningkatan dan/atau perbaikan sarana dan prasarana fisik pelayanan dasar masyarakat dengan umur ekonomis yang panjang, termasuk pengadaan sarana fisik penunjang.

Daerah tertentu yang dimaksud adalah daerah yang memenuhi kriteria yang ditetapkan setiap tahun untuk mendapatkan alokasi Dana Alokasi Khusus (DAK). Dengan demikian, tidak semua daerah mendapatkan alokasi Dana Alokasi Khusus (DAK). Hal yang dimaksud dengan fungsi dalam rincian belanja negara antara lain terdiri atas layanan umum, pertahanan, ketertiban 
dan keamanan, ekonomi, lingkungan hidup, perumahan dan fasilitas umum, kesehatan, pariwisata, budaya, agama, pendidikan, dan perlindungan sosial.

Daerah tertentu yang dapat memperoleh alokasi Dana Alokasi Khusus (DAK) ditentukan berdasarkan kriteria umum, kriteria khusus, dan kriteria teknis. Kriteria umum berarti mempertimbangkan kemampuan keuangan daerah dalam APBD. Kriteria khusus berarti memerhatikan peraturan perundang-undangan dan karakteristik daerah. Kriteria teknis merupakan kriteria yang ditetapkan oleh kementerian negara atau departemen teknis. Daerah penerima Dana Alokasi Khusus (DAK) wajib menyediakan Dana Pendamping sekurang-kurangnya $10 \%$ dari alokasi Dana Alokasi Khusus (DAK). Dana Pendamping harus dianggarkan dalam APBD, namun bagi daerah dengan kemampuan fiskal tertentu tidak diwajibkan menyediakan dana pendamping.

Pemberian Dana Alokasi Khsusus (DAK) oleh pemerintah yang dialokasikan bagi daerah tertentu bertujuan untuk mendanai kegiatan tertentu yang menjadi prioritas nasional. Jadi, penggunaan Dana Alokasi Khsusus (DAK) telah ditentukan oleh pemerintah pusat, sehingga daerah tidak dapat membelanjakannya untuk kebutuhan lain. Daerah yang memenuhi kriteria pada setiap tahunnya akan diberikan Dana Alokasi Khsusus (DAK). Penggunaan dana tersebut diutamakan untuk proses pembangunan yang menyangkut infrastruktur maupun sarana dan prasarana fisik pelayanan dasar masyarakat. Dengan Dana Alokasi Khsusus (DAK) diharapkan terjadi pemerataan dalam pembangunan, serta pelayanan bagi masyarakat. Daerah yang keuangannya kurang mencukupi akan terbantu oleh Dana Alokasi Khsusus (DAK), sehingga dapat meminimalisir kecemburuan antardaerah. Di samping itu pula diharapkan dapat mencapai standar pelayanan minimal bagi setiap daerah, karena masyarakat memiliki hak untuk mendapatkan pelayanan yang baik. Oleh karena itu, Dana Alokasi Khsusus (DAK) menjadi sangat penting fungsinya untuk mencapai kegiatan yang menjadi program nasional. 
Tabel 4.2

Rekapitulasi Umum Alokasi Dana Alokasi Khusus (DAK) Sub Bidang Prasarana Pemerintahan Tahun Anggaran 2016

\begin{tabular}{|c|c|c|c|}
\hline No. & Provinsi & $\begin{array}{c}\text { Jumlah } \\
\text { Kab/Kota }\end{array}$ & Jumlah Alokasi \\
\hline 1 & Aceh & 5 & 16.534 .070 .000 \\
\hline 2 & Sumatera Utara & 5 & 14.830 .970 .000 \\
\hline 3 & Sumatera Barat & 1 & 1.826 .790 .000 \\
\hline 4 & Riau & 1 & 521.850 .000 \\
\hline 5 & Kepri & 1 & 1.423 .960 .000 \\
\hline 6 & Sumatera Selatan & 5 & 8.088 .420 .000 \\
\hline 7 & Lampung & 3 & 2.372 .760 .000 \\
\hline 8 & Jawa Barat & 2 & 9.919 .100 .000 \\
\hline 9 & Banten & 2 & 6.939 .260 .000 \\
\hline 10 & Jawa Tengah & 2 & 7.027 .690 .000 \\
\hline 11 & Jawa Timur & 2 & 8.263 .800 .000 \\
\hline 12 & Kalimantan Utara & $1 *$ & 6.156 .290 .000 \\
\hline 13 & Kalimantan Barat & 1 & 4.982 .370 .000 \\
\hline 14 & Kalimantan Tengah & 1 & 344.930 .000 \\
\hline 15 & Kalimantan Timur & 1 & 433.700 .000 \\
\hline 16 & Sulawesi Utara & 2 & 2.000 .890 .000 \\
\hline 17 & Gorontalo & 1 & 2.097 .350 .000 \\
\hline 18 & Sulawesi Tengah & 6 & 16.840 .446 .000 \\
\hline 19 & Sulawesi Selatan & 6 & 14.128 .940 .000 \\
\hline
\end{tabular}


362 | Mendra Wijaya, Handrisal.Implementasi Program...|

\begin{tabular}{|c|l|c|r|}
\hline 20 & Sulawesi Barat & 1 & 2.520 .680 .000 \\
\hline 21 & Sulawesi Tenggara & 6 & 9.004 .500 .000 \\
\hline 22 & Bali & 1 & 1.484 .200 .000 \\
\hline 23 & NTB & 2 & 4.468 .120 .000 \\
\hline 24 & NTT & 4 & 3.116 .180 .000 \\
\hline 25 & Maluku & 2 & 1.067 .280 .000 \\
\hline 26 & Maluku Utara & 2 & 10.000 .470 .000 \\
\hline 27 & Papua & 3 & 15.656 .150 .000 \\
\hline 28 & Papua Barat & 73 & 175.520 .706 .000 \\
\hline & JUMLAH & 3.469 .540 .000 & \\
\hline
\end{tabular}

\section{B. Isu-Isu Pokok Dalam Penyelenggaraan Dana Alokasi Khusus (Dak) Sub Bidang Sarana Pemerintahan Daerah \\ a. Dampak Kebijakan Pemerintah Pusat}

Umumnya Anggaran Pendapatan Belanja Daerah (APBD) suatu daerah didominasi oleh suatu transfer pemerintah pusat dan transfer yang lain, yang diatur dengan peraturan perundang-undangan. Hal ini menyebabkan pemerintah daerah sangat tergantung dari pemerintah pusat sehingga kemampuan daerah untuk mengembangkan potensi yang mereka miliki menjadi sangat terbatas. Rendahnya PAD suatu daerah bukanlah disebabkan karena secara struktural daerah memang miskin atau tidak memiliki sumbersumber keuangan yang potensial, tetapi lebih banyak disebabkan oleh kebijakan pemerintah pusat.

Dana Alokasi Khusus (DAK) dialokasikan dari APBN kepada daerah tertentu dalam rangka pendanaan pelaksanaan desentralisasi untuk mendanai kegiatan khusus yang ditentukan pemerintah atas dasar prioritas nasioanal. Kegiatan khusus tersebut sesuai dengan fungsi yang telah ditetapkan dalam APBN. Kegiatan khusus yang ditetapkan oleh pemerintah mengutamakan kegiatan pembangunan dan/atau pengadaan dan/atau peningkatan dan/atau 
perbaikan sarana dan prasarana fisik pelayanan dasar masyarakat dengan umur ekonomis yang panjang.

Pemerintah Pusat dan Pemerintah Daerah tidak bermaksud menggunakan wewenang merencanakan defisit fiskal, secara nasional selalu diupayakan agar :

1. anggaran selalu berimbang, defisit anggaran APBN \& APBD tidak lebih besar dari 3 \% PDB NKRI, dan

2. nisbah utang pemerintah pusat dan daerah tidak lebih besar dari $60 \%$ PDB NKRI.

Seperti misalnya terjadi pemotongan anggaran $10 \%$ sesuai Dana Akolasi Umum (DAK) melalui Surat Edaran Menteri Keuangan No. SE10/MK.07/2016 tentang pengurangan/Pemotongan Dana Alokasi Khusus (DAK) Fisik Secara Mandiri Tahun Anggaran 2016. Sementara kebutuhan daerah terhadap Dana Alokasi Khusus (DAK) terus meningkat, khususnya anggaran infrastruktu.

TABEL 4.3

PERTUMBUHAN DAK

\begin{tabular}{|l|r|r|r|r|}
\hline \multicolumn{1}{|c|}{ Uraian } & \multirow{2}{*}{$\mathbf{2 0 1 4}$} & \multicolumn{2}{|c|}{$\mathbf{2 0 1 5}$} & APBN \\
& & APBNP & Real* & $\mathbf{2 0 1 6}$ \\
\hline I. Insfrastruktur Ekonomi & 144,4 & 280,3 & 247,5 & 302,6 \\
1. Melalui Belanja K/L & 118,6 & 196,8 & 170,3 & 165,5 \\
a.I. 033 Kementerian Pekerjaan & 69,3 & 111,1 & 107,4 & 101,7 \\
Umum dan Perumahan Rakyat & & & & \\
022 Kementerian Perhubungan & 26,2 & 59,1 & 44,4 & 45,5 \\
018 Kementerian Pertanian & 1,8 & 8,9 & 8,1 & 5,3 \\
020 Kementerian ESDM & 4,0 & 8,1 & 4,4 & 4,6 \\
& & & & \\
2. Melalui Belanja Non K/L & 2,5 & 6,8 & 4,1 & 5,3 \\
a.I. 1. VGF (termasuk cadangan & - & 1,2 & - & 1,1 \\
VGF) & & & & \\
2. Belanja Hibah & 0,8 & 4,5 & 3,0 & 4,0 \\
& & & & \\
\hline
\end{tabular}


364 | Mendra Wijaya, Handrisal.Implementasi Program...|

\begin{tabular}{|l|r|r|r|r|}
\hline \multirow{2}{*}{ Uraian } & \multirow{2}{*}{$\mathbf{2 0 1 4}$} & \multicolumn{2}{|c|}{$\mathbf{2 0 1 5}$} & APBN \\
\cline { 4 - 5 } & & APBNP & Real* & $\mathbf{2 0 1 6}$ \\
\hline 3. Melalui Transfer Daerah dan & 14,4 & 41,0 & 39,1 & 83,4 \\
Dana Desa & & & & \\
a.I. 1. Dana Alokasi Khusus & $\mathbf{1 1 , 9}$ & $\mathbf{2 9 , 7}$ & $\mathbf{2 7 , 7}$ & $\mathbf{6 2 , 8}$ \\
2. Perkiraan Dana Desa untuk & - & 8,3 & 8,3 & 18,8 \\
infrastruktur & & & & \\
& & & & \\
4. Melalui Pembiayaan & & & & \\
a.I. 1. FLPP & & & & \\
2. Penyertaan Modal Negara & 9,0 & 35,7 & 34,1 & 48,3 \\
& 3,0 & 5,1 & 5,1 & 9,2 \\
& 4,0 & 28,8 & 28,8 & 38,2 \\
\hline Infrastruktur Sosial & 8,0 & 6,3 & 5,8 & 6,5 \\
a.I. 023 Kementerian Pendidikan & 6,6 & 4,3 & 3,9 & 5,3 \\
dan Kebudayaan & 0,9 & 2,1 & 2,0 & 1,2 \\
025 Kementerian Agama & & & & \\
\hline III. Dukungan Infrastruktur & 2,1 & 3,7 & 2,9 & 4,4 \\
a.I. 056 PBN & 0,0 & 1,3 & 0,9 & 0,3 \\
019 Kemenperin & 0,1 & 0,6 & 0,6 & 0,5 \\
\hline Jumlah & $\mathbf{1 5 4 , 6}$ & $\mathbf{2 9 0 , 3}$ & $\mathbf{2 5 6 , 3}$ & $\mathbf{3 1 3 , 5}$ \\
\hline
\end{tabular}

Sumber : Kementerian Keuangan Republik Indonesia Tahun 2016

Resiko pertumbuhan DAK karena pertambahan bidang baru aloksasi DAK dan risiko kesalahan atau ketidakadilan alokasi. Dengan demikian alokasi DAK mencakup : Bidang pendidikan, Bidang kesehatan Bidang jalan, Bidang irigasi, Bidang prasarana pemerintahan, Bidang kelautan \& perikanan, Bidang air bersih, Bidang pertanian, Bidang lingkungan hidup, Bidang keluarga berencana, Bidang kehutanan, Bidang perdagangan, Bidang sarana \& prasarana pedesaan, Bidang sanitasi, Bidang listrik pedesaa, Bidang perumahan dan pemukiman, Bidang keselamatan transportasi pedesaan, serta Bidang sarana dan prasarana perbatasan. 


\section{Belum Optimalnya Laporan Evaluasi Penyelenggaraan Dana Alokasi Khusus (DAK) Sub Bidang Prasarana Pemerintahan Daerah}

Dalam penetapan program dan kegiatan penyelenggaraan Dana Alokasi Khusus (DAK) Pasal 52 Peraturan Pemerintah (PP) Nomor 55 Tahun 2005 menyatakan bahwa program yang menjadi prioritas nasional dimuat dalam Rencana Kerja Pemerintah (RKP) tahun anggaran bersangkutan. Sementara itu, menteri teknis mengusulkan kegiatan khusus yang akan di danai dari DAK dan ditetapkan setelah berkoordinasi dengan Menteri Dalam Negeri, Menteri Keuangan, dan Menteri Negara Perencanaan Pembangunan Nasional, sesuai dengan RKP. Selanjutnya, menteri teknis menyampaikan ketetapan mengenai kegiatan khusus tersebut kepada Menteri Keuangan, yang akan dipergunakan oleh Menteri Keuangan untuk melakukan perhitungan alokasi DAK.

Dalam Pasal 8 Undang-Undang Nomor 23 Tahun 2014 tentang Pemerintahan Daerah menegaskan bahwa Binwas penyelenggaraan urusan Pemerintahan oleh Daerah secara nasional dikoordinasikan oleh Mendagri. Kemudian pada Pasal 59 Peraturan Pemerintah Nomor 55 Tahun 2004 tentang Dana Perimbangan berbunyi bahwa Menteri Teknis menyusun Petunjuk Teknis DAK penggunaan DAK yang dikoordinasikan oleh Menteri Dalam Negeri. dan Pasal 60 berbunyi Bahwa Daerah Penerima DAK wajib mencantumkan alokasi dan penggunaan DAK di dalam APBD dan Penggunaan DAK dimaksud dilakukan sesuai dengan Petunjuk Teknis Penggunaan DAK.

Berikutnya di dalam pasal 2 ayat (1) Peraturan Menteri Dalam Negeri Republik Indonesia Nomor 85 Tahun 2015 Tentang Petunjuk Teknis Penggunaan Dana Alokasi Khusus Sub-Bidang Prasarana Pemerintahan Daerah, Sub-Bidang Sarana dan Prasarana Satuan Polisi Pamong Praja, SubBidang Sarana dan Prasarana Pemadam Kebakaran, Dan Sub-Bidang Transportasi Perdesaan, berbunyi Pasal 2 DAK yang dikoordinasikan Kementerian Dalam Negeri, meliputi, DAK Bidang Prasarana Pemda dan DAK Bidang Transportasi. Lalu Pasal 3 ayat (1) berbunyi dalam rangka kelancaran koordinasi DAK dibentuk Tim Koordinasi Pembinaan DAK Kementerian Dalam Negeri. 
Pasal 11 ayat (1) berbunyi Gubernur dan Bupati/Walikota mengkoordinasikan pemantauan dan evaluasi pelaksanaan DAK, dan ayat (2) Hasil pemantauan dan evaluasi dilaporkan secara periodik triwulanan dan akhir tahun kepada Menteri melalui Pembina DAK.

Peraturan Menteri Dalam Negeri Republik Indonesia Nomor 85 Tahun 2015 Tentang Petunjuk Teknis Penggunaan Dana Alokasi Khusus Sub-Bidang Prasarana Pemerintahan Daerah, Sub-Bidang Sarana dan Prasarana Satuan Polisi Pamong Praja, Sub-Bidang Sarana dan Prasarana Pemadam Kebakaran, Dan Sub-Bidang Transportasi Perdesaan, berbunyi Pasal 2 DAK yang dikoordinasikan Kementerian Dalam Negeri, meliputi, DAK Bidang Prasarana Pemda dan DAK Bidang Transportasi berbeda dengan Petunjuk Teknis Penggunaan Dana Alokasi Khusus Sub-Bidang Prasarana Pemerintahan Daerah sebelumnya yaitu Peraturan Menteri Dalam Negeri Republik Indonesia Nomor 103 Tahun 2014 Tentang Petunjuk Teknis Pengelolaan Dana Alokasi Khusus Kementerian Dalam Negeri Tahun 2015.

Pada Peraturan Menteri Dalam Negeri Republik Indonesia Nomor 103 Tahun 2014 Tentang Petunjuk Teknis Pengelolaan Dana Alokasi Khusus Kementerian Dalam Negeri Tahun 2015, mengenai pengawasan pada pasal 20 ayat (2) berbunyi Penyimpangan dalam pelaksanaan DAK yang tidak sesuai dengan Petunjuk Teknis dikenakan sanksi berupa :

a. Tidak diusulkan untuk mendapatkan alokasi DAK pada tahun berikutnya

b. Mengganti seluruhnya atau sebagian anggaran yang tidak sesuai dengan pelaksanaannya melalui APBD.

Sementara dalam Peraturan Menteri Dalam Negeri Republik Indonesia Nomor 85 Tahun 2015 Tentang Petunjuk Teknis Penggunaan Dana Alokasi Khusus Sub-Bidang Prasarana Pemerintahan Daerah, Sub-Bidang Sarana dan Prasarana Satuan Polisi Pamong Praja, Sub-Bidang Sarana dan Prasarana Pemadam Kebakaran, Dan Sub-Bidang Transportasi Perdesaan, tidak memuat ketentuan khusus mengenai pengawasan seperti halnya petunjuk teknis sebelumnya.

Di dalam Peraturan Menteri Dalam Negeri Republik Indonesia Nomor 85 Tahun 2015, Pasal 12 berbunyi : pengawasan terhadap pelaksanaan 
kegiatan dan pengelolaan keuangan DAK dilakukan sesuai ketentuan peraturan perundang-undangan. Sedangkan sebelumnya pada Peraturan Menteri Dalam Negeri Republik Indonesia Nomor 103 Tahun 2014, memuat tegas dalam Pasal 20 ayat (1) berbunyi : Pengawasan terhadap pelaksanaan kegiatan dan pengelolaan keuangan DAK dilakukan sesuai ketentuan peraturan perundang-undangan. Sama seperti isi pada pasal 12 Peraturan Menteri Dalam Negeri Republik Indonesia Nomor 85 Tahun 2015. Sedangkan kriteria sanksi tidak dimuat dalam Peraturan Menteri Dalam Negeri Republik Indonesia Nomor 85 Tahun 2015 seperti yang termuat pada pasal 20 ayat (2) Peraturan Menteri Dalam Negeri Republik Indonesia Nomor 103 Tahun 2014.

Dengan demikian dapat diasumsikan bahwa daerah yang menerima Dana Alokasi Khusus (DAK) Sub Bidang Prasarana Pemerintahan Daerah Tahun Anggaran 2016, yang melalaikan bahkan mengabaikan pelaporan triwulan dalam melaksanakan DAK tidak sesuai dengan petunjuk teknis, maka tidak ada ketentuan sanksi yang mengikat secara hukum dan administrasi sehingga daerah tidak memiliki beban psikologis dan beban administratif dalam melaksanakan pelaporan penyelenggaraan Dana Alokasi Khusus (DAK) Sub Bidang Prasarana Pemerintahan Daerah Tahun Anggaran 2016.

Dengan demikian, untuk pelaksanaan Dana Alokasi Khusus (DAK) Sub Bidang Prasarana Pemerintahan Daerah berikutnya memuat ketentuan yang mengatur tentang pengawasan secera rinci agar pelaporan penyenggaraan Dana Alokasi Khusus (DAK) Sub Bidang Prasarana Pemerintahan Daerah lebih optimal, transparan dan profesional.

Untuk pendanaan pembangunan yang berasal dari DAK (Dana Alokasi Khusus), meskipun proporsinya terhadap keseluruhan dana perimbangan masih kecil munculnya berbagai perspektif dan kendala akhir-akhir ini perlu dikaji secara sistematik dan direspon dengan kebijakan yang lebih selaras serta efektif. Tidak dapat dipungkiri bahwa bagi daerah tertentu, terutama daerah-daerah yang memiliki kemampuan fiskal rendah dan sebagian besar Dana Alokasi Umum (DAU)-nya terpakai untuk gaji pegawai dan belanja rutin lainnya, DAK (Dana Alokasi Khusus) masih tetap menjadi sumber pembiayan pembangunan yang penting. Alasan utamanya adalah bagaimana pemerintah daerah akan memaksimalkan pelayanan publik sementara infrastruktur penunjang kurang efektif. 


\section{PENUTUP}

Tujuan pengalokasian Dana Akolasi Khusus (DAK) antara lain adalah untuk meningkatkan penyediaan sarana dan prasarana fisik yang menjadi prioritas nasional dan meningkatkan pertumbuhan ekonomi guna menyerasikan laju pertumbuhan antardaerah serta pelayanan antar sektor.

Pemerintah pusat memangkas Dana Akolasi Khusus (DAK) melalui Surat Edaran Menteri Keuangan No. SE-10/MK.07/2016 tentang pengurangan/Pemotongan Dana Alokasi Khusus (DAK) Fisik Secara Mandiri Tahun Anggaran 2016 yang ditetapkan pada 8 April 2016 di seluruh Kementerian dan Kabupaten di Indonesia, karena adanya perubahan asumsi makro dan target penerimaan negara, sebagai dampak ekonomi domestik dan global.

Rancangan Perubahan APBN Tahun Anggaran 2016 tersebut mencakup penurunan target Penerimaan Negara dan pengurangan Belanja Negara, baik Belanja Pamerintah Pusat (khususnya Belanja Kementerian/Lembaga), maupun Transfer ke Daerah dan Dana Desa. Rancangan Perubahan APBN Tahun Anggaran 2016 tersebut diajukan Pameriritah kepada DPR Rl yang dibahas pada bulan Mei Tahun 2016. Rencana penurunan Transfer ke Daerah dan Dana Desa akan dibebankan pada pengurangan/pemotongan Dana Alokasi Khusus (DAK) Fisik dengan mengurangi/memotong secara mandiri (self blocking) sebesar minimal 10\% (sepuluh persen) dari total pagu alokasi Dana Akolasi Khusus (DAK) Fisik Tahun Anggaran 2016.

Dalam APBN 2016, Dana Transfer Khusus (DTK) dialokasikan Rp. 208,91 trilun. Dari pagu tersebut, alokasi DAK Fisik Rp. 85,44 triliun. Sementara alokasi DAK Non Fisik senilai Rp. 123,48 triliun. DAK Fisik terdiri atas DAK Reguler Rp. 55,1 triliun, DAK Infrastruktur dan Publik Daerah Rp. 27,5 triliun, dan DAK Afirmasi Rp. 2,8 triliun.

Kebijakan pemerintah pusat yang melakukan pemotongan Dana Akolasi Khusus (DAK), berpengaruh pada program pembangunan yang tertuang di APBD khususnya dari sektor pendapatan daerah. Akibat pengurangan dana tersebut, anggaran untuk pembangunan infrastruktur di 
beberapa SKPD yang dananya bersumber dari Dana Akolasi Umum (DAK) juga akan ikut dipangkas.

\section{DAFTAR PUSTAKA}

\section{Buku:}

Dumairy. 2006. Perekonomian Indonesia. Erlangga. Jakarta.

Halim, Abdul. 2002. Akuntansi Keuangan Daerah. Salemba Empat.

Mangkoesoebroto, Guritno. 2010. Ekonomi Publik. BPFE. Yogyakarta. 2002.

Rahayu, Ani Sri, Pengantar Kebijakan Fiskal, Bumi Aksara, Jakarta, 2010.

Yani, Ahmad. 2009. Hubungan Keuangan antara Pemerintah Pusat dan Daerah di Indonesia. Rajawali Pers. Jakarta.

Yustika, Ahmad Erani, ed. 2008. Desentralisasi Ekonomi di Indonesia Kajian Teoritis dan Realitas Empiris. Bayumedia. Malang.

\section{Jurnal:}

Brixi, H. P. (2001). Government Contingent Liabilities : A Hidden Risk To Fiscal Stability. Journal of Public Budgeting, Accounting \& Financial Management , 13 (4), 582-625.

Brixi, H. P., \& Mody, A. (2002). Dealing With Government Fiscal Risk : An Overview. In H. P. Brixi, \& A. Schick (Eds.), Government at Risk, Contingent Liabilities and Fiscal Risk (pp. 21-58). Washington, D.C.: World Bank and Oxford University Press.

Cottarelli, C. (2014). Fiscal Sustainability And Fiscal Risk : An Analytical Framework. In C. Cottarelli, P. Gerson, \& A. Senhadji (Eds.), Post-crisis Fiscal Policy (pp. 15-30). London: MIT and IMF.

\section{Peraturan Perindang-undangan:}

Undang-Undang Nomor 17 Tahun 2003 tentang Keuangan Negara.

Undang-Undang Nomor 25 Tahun 2004 tentang Sistem Perencanaan Pembangunan Nasional.

Undang-Undang Nomor 33 Tahun 2004 tentang Perimbangan Keuangan Antara Pemerintah Pusat dan Pemerintahan Daerah. 
370 | Mendra Wijaya, Handrisal.Implementasi Program...

Undang-Undang Nomor 23 Tahun 2014 tentang Pemerintahan Daerah.

Peraturan Pemerintah Nomor 55 Tahun 2005 tentang Dana Perimbangan.

Peraturan Presiden No. 137 Tahun 2015 Tentang Rincian Anggaran Pendapatan Dan Belanja Negara Tahun Anggaran 2016.

Peraturan Menteri Dalam Negeri Nomor 13 Tahun 2006 tentang Pedoman Pengelolaan Keuangan Daerah, sebagaimana telah diubah terakhir dengan Peraturan Menteri Dalam Negeri Nomor 21 Tahun 2011.

Peraturan Menteri Dalam Negeri Nomor 20 Tahun 2009 tentang Pedoman Pengelolaan Keuangan Dana Alokasi Khusus di Daerah, sebagaimana telah diubah dengan Peraturan Menteri Dalam Negeri Nomor 59 Tahun 2010.

Peraturan Menteri Dalam Negeri Nomor 43 Tahun 2015 tentang Organisasi dan Tata Kerja Kementerian Dalam Negeri.

Peraturan Menteri Dalam Negeri Nomor 54 Tahun 2015 tentang Rencana Strategis Kementerian Dalam Negeri Tahun 2015-2019.

Peraturan Menteri Dalam Negeri Republik Indonesia Nomor 85 Tahun 2015 Tentang Petunjuk Teknis Penggunaan Dana Alokasi Khusus Sub-Bidang Prasarana Pemerintahan Daerah, Sub-Bidang Sarana dan Prasarana Satuan Polisi Pamong Praja, Sub-Bidang Sarana dan Prasarana Pemadam Kebakaran, dan Sub-Bidang Transportasi Perdesaan. 